\title{
KREATIFITAS KEWIRAUSAHAAN SOSIAL DAN MENGGALI IDE USAHA BARU MELALUI PENGOLAHAN KRIPIK TEMPE LUPIN
}

\author{
Dedi Rianto Rahadi ${ }^{1}$ \\ Universitas Presiden \\ Email: dedi1968@president.ac.id \\ Etty Susilowaty ${ }^{2}$ \\ Universitas Presiden \\ Email: ettys@president.ac.id
}

\begin{abstract}
The main social problems that occurred in Indonesia, among others: unemployment and poverty. Such conditions can certainly interfere with national development and stability. Therefore, what is needed now is a real solution that can help overcome the problems. One such solution is to increase the entrepreneurial spirit in each individual in society, especially the youth as the backbone of the nation, particularly through the development of social entrepreneurship. Social entrepreneurship is expected to generate new business ideas which in turn has an impact reducing unemployment and poverty. The implementation of the Community Service was conducted using lectures and practical method to create and modify lupine tempe chips product with processed materials by the participants. Lupine tempe chips is a traditional food from Indonesia made from Soybeans, a kind of nuts from Lupinus Angustifolius plant (Lupine leafy-leafed) cultivated in Australia. The results demonstrate community service, lupine tempe chips processing training is an attempt to foster social entrepreneurial ventures and bring new business ideas. New ideas are generated, the participants not only creative with tempeh chips but a wide range of raw material processed tempe. Therefore, social entrepreneurship training activities in making tempe chips LUPIN this goes well. This is shown by the growth of spirit, motivation and creativity in exploring the idea of business potential.
\end{abstract}

Keywords: social entrepreneurship, social issues, new idea

ABSTRAK: Masalah sosial utama yang terjadi di Indonesia antara lain: pengangguran dan kemiskinan. Kondisi tersebut tentunya dapat mengganggu pembangunan dan stabilitas nasional. Oleh karena itu, yang dibutuhkan saat ini adalah suatu solusi nyata yang dapat membantu mengatasi permasalahan. Salah satu solusi tersebut adalah dengan meningkatkan semangat kewirausahaan pada setiap individu yang ada di masyarakat, terutama pemuda sebagai tulang punggung bangsa, diantaranya melalui pengembangan kewirausahaan sosial. Kewirausahaan sosial diharapkan dapat menimbulkan ide usaha baru yang pada akhirnya memiliki dampak mengurangi pengganguran dan kemisikinan. Pelaksanaan kegiatan Pengabdian Pada Masyarakat ini dilakukan dengan menggunakan metode ceramah dan pratek dalam membuat keripik tempe LUPIN serta memodifikasi produk dengan bahan olahan oleh peserta. Keripik tempe LUPIN sendiri merupakan makanan tradisional dari Indonesia yang dibuat dari Kedelai, sejenis kacang-kacangan dari tanaman Lupinus Angustifolius (Lupin berdaun runcing) yang dibudidayakan di Australia. Hasil pengabdian masyarakat memperlihatkan, pelatihan pengolahan kripik tempe lupin adalah suatu upaya untuk menumbuhkan usaha kewirausahaan sosial dan memunculkan ide-ide usaha baru. Ide baru yang dihasilkan, peserta tidak hanya berkreasi dengan kripik tempe melainkan berbagai macam olahan berbahan baku tempe. Oleh karena itu, kegiatan pelatihan kewirausahaan sosial dalam pembuatan kripik tempe LUPIN ini berlangsung dengan baik. Hal ini ditunjukkan dengan tumbuhnya spirit, motivasi dan kreatifitas dalam menggali ide potensi usaha.

Kata Kunci: kewirausahaan sosial, masalah sosial, ide baru

PENDAHULUAN
Latar Belakang
Penanggulangan
pengangguran telah dilakukan oleh
pemerintah dengan mencanangkan gerakan
kewirausahaan. Salah satu model
kewirausahaan yang akan dikembangkan
adalah kewirausahaan sosial dengan
menekankan pada keterlibatan semua

anggota untuk meningkatkan kepedulian dengan sesama.

Wirausaha sosial melihat masalah sebagai peluang untuk membentuk sebuah model bisnis baru yang bermanfaat bagi pemberdayaan masyarakat sekitar. Hibbert, Hogg, and Quinn dalam Hardi (2014) mengungkapkan bahwa kewirausahaan sosial adalah pemanfaatan perilaku 
kewirausahaan yang lebih berorientasi untuk pencapaian tujuan sosial dan tidak mengutamakan perolehan laba, atau laba yang diperoleh dimanfaatkan untuk kepentingan soaial. Menurut Rhenald (2008), banyak orang bicara tentang wirausaha, namun mereka belum paham. Saat ini banyak mentor yang mengajarkan kewirausahaan dengan cara cepat kaya. Padahal dalam kewirausahaan sosial hal yang menjadi pegangan yakni misi sosial, produk atau servis yang ditukar, dan keuntungan yang dicari didistribusikan bukan untuk kepentingan diri sendiri, serta harus dapat mempertanggungjawabkan terhadap apa yang disalurkan. "Dalam kewirausahaan sosial, tidak hanya orang kaya yang bisa berbagi. Disini, orang miskinpun bisa berbagi”.

Salah satu kegiatan pengabdian masyarakat yang akan dilakukan team dosen universitas presiden untuk menumbuhkan kemandirian dalam melakukan kewirausahaan sosial adalah memberikan pelatihan pembuatan kripik tempe lupin pada KUP Suta Nusantara (Komunitas Usaha Pertanian Sentra Usaha Tani dan Agribisnis Nusantara) di daerah Surabaya. Kripik Tempe Lupin adalah makanan tradisional dari Indonesia yang dibuat dari Kedelai, namun ada inovasi baru dari pembuatan Tempe yaitu dibuat dari Lupin. Lupin adalah sejenis kacangkacangan dari tanaman Lupinus Angustifolius (Lupin berdaun runcing) yang dibudidayakan di Australia. Di Eropa, lupin digunakan untuk menggantikan biji-bijian sereal atau kedelai dalam produk makanan panggang, makanan kecil, mie dan pasta. Bahkan diperkirakan bahwa 500.000 ton produk makanan di Eropa mengandung Lupin putih Eropa dan Lupin manis Australia sebagai bahan bakunya. Inovasi ini sangat berguna bagi masyarakat di Indonesia, karena masalah krisis Kedelai yang sangat mengancam para pekerja pembuat Tempe.

Tujuan pengabdian masyarakat adalah untuk menumbuhkan jiwa kewirausahaan dan dan mampu memberikan manfaat bagi masyarakat sekitarnya. Manfaaat tersebut dapat berujud manfaat finansial maupun non finansial.
Manfaat finansial dari kewirausahaan dapat berupa kemandirian ekonomi yang diperoleh dalam menjalankan usaha. Sedangkan manfaat non finansial berupa penumbuhan mental yang tangguh dan pantang menyerah dalam menghadapai permasalahan hidup.

Berdasarkan uraian yang telah dijelaskan sebelumnya, perlu diadakan pelatihan kewirausahaan bagi masyarakat khususnya bagi anggota keluarga Komunitas Usaha Pertanian Sentra Usaha Tani dan Agribisnis Nusantara) di daerah Surabaya. Harapan dari peneliti, pelatihan yang akan dilakukan dapat menumbuhkan kreatifitas kewirausahaan dan menggali potensi yang ada. Dengan diadakan pelatihan kewirausahaan diharapkan mampu memunculkan usaha baru dan memberikan efek positif pada pengembangan mental kemandirian generasi muda.

\section{Identifikasi dan Perumusan Masalah}

Berdasarkan uraian sebelumnya, dapat diidentifikasikan permasalahan sebagai berikut:

1. Masih minimnya social entrepreneuship yang bergerak dibidang pengolahan keripik tempe LUPIN.

2. Masih rendahnya spirit keluarga KUP Suta Nusantara (Komunitas Usaha Pertanian Sentra Usaha Tani dan Agribisnis Nusantara) dalam berwirausaha khususnya yang bergerak dibidang pengolahan keripik tempe LUPIN.

3. Masih kurangnya kreativitas untuk menggali ide potensi usaha baru keluarga pada KUP Suta Nusantara (Komunitas Usaha Pertanian Sentra Usaha Tani dan Agribisnis Nusantara).

Berdasarkan identifikasi masalah tersebut, maka rumusan masalah dalam kegiatan pengabdian ini adalah:

1. Bagaimana menumbuhkan spirit, motivasi, dan kreativitas kerwirausahaan sosial kepada keluarga KUP Suta Nusantara (Komunitas Usaha Pertanian Sentra Usaha Tani dan Agribisnis Nusantara). 
2. Bagaimana memberikan pengetahuan yang memadai dalam pengolahan keripik tempe LUPIN.

\section{Tujuan dan Manfaat Kegiatan}

Tujuan kegiatan Program Pengabdian

Masyarakat (PPM) ini adalah:

1. Menumbuhkan spirit, motivasi, dan kreativitas kerwirausahaan sosial kepada keluarga KUP Suta Nusantara (Komunitas Usaha Pertanian Sentra Usaha Tani dan Agribisnis Nusantara).

2. Memberikan pengetahuan yang memadai untuk membuat keripik tempe LUPIN.

Manfaat kegiatan PPM ini adalah:

1. Bagi para peserta dapat memiliki spirit, motivasi untuk membentuk kerwirausahaan sosial .

2. Bagi lembaga yang terkait, yaitu Universitas Presiden dan masyarakat diharapkan dapat terjalinnya kerja sama yang semakin erat, sehingga memberikan kontribusi positif pada kedua belah pihak

\section{TINJAUAN PUSTAKA}

\section{Konsep Kewirausahaan Sosial}

Bill Drayton (pendiri Ashoka

Foundation) selaku penggagas

kewirausahaan sosial menegaskan bahwa ada dua hal kunci dalam kewirausahaan sosial. Pertama, adanya inovasi sosial yang mampu mengubah sistem yang ada di masyarakat. Kedua, hadirnya individu bervisi, kreatif, berjiwa wirausaha (entrepreneurial), dan beretika di belakang gagasan inovatif tersebut. Hulgard (2010) merangkum definisi kewirausahaan sosial dengan lebih komprehensif: "Social entrepreneurship can be defined as "the creation of a social value that is produced in collaboration with people and organization from the civil society who are engaged in social innovations that usually imply an economic activity".

Definisi komprehensif di atas memberikan pemahaman bahwa kewirausahaan sosial terdiri dari empat elemen utama yakni social value, civil society, innovation, dan economic activity.

1. Social Value. Ini merupakan elemen paling khas dari kewirausahaan sosial yakni menciptakan manfaat sosial yang nyata bagi masyarakat dan lingkungan sekitar.

2. Civil Society. Kewirausahaan sosial pada umumnya berasal dari inisiatif dan partisipasi masyarakat sipil dengan mengoptimalkan modal sosial yang ada di masyarakat.

3. Innovation. Kewirausahaan sosial memecahkan masalah sosial dengan cara-cara inovatif antara lain dengan memadukan kearifan lokal dan inovasi sosial.

4. Economic Activity. Kewirausahaan sosial yang berhasil pada umumnya dengan menyeimbangkan antara aktivitas sosial dan aktivitas bisnis. Aktivitas bisnis/ekonomi dikembangkan untuk menjamin kemandirian dan keberlanjutan misi sosial organisasi.

\section{Karakteristik Social Entrepreneur}

Karakteristik yang dimiliki social entrepreneur menurut Borstein (2006) dijelaskan sebagai berikut:

1. Orang-orang yang mempunyai visi untuk memecahkan masalah masalah kemasyarakatan sebagai pembaharu masyarakat dengan gagasan-gagasan yang sangat kuat untuk memperbaiki taraf hidup masyarakat.

2. Umumnya bukan orang terkenal, misal : dokter, pengacara, insinyur, konsultan manajemen, pekerja sosial, guru dan wartawan.

3. Orang-orang yang memiliki daya transformatif, yakni orang-orang dengan gagasan baru dalam menghadapi masalah besar, yang tak kenal lelah dalam mewujudkan misinya, menyukai tantangan, punya daya tahan tinggi, orang-orang yang sungguh-sungguh tidak mengenal kata menyerah hingga mereka berhasil menyebarkan gagasannya sejauh mereka mampu.

4. Orang yang mampu mengubah daya kinerja masyarakat dengan cara terus memperbaiki, memperkuat, dan memperluas cita-cita.

5. Orang yang memajukan perubahan sistemik: bagaimana mereka mengubah pola perilaku dan pemahaman.

6. Pemecah masalah paling kreatif. 
7. Mampu menjangkau jauh lebih banyak orang dengan uang atau sumber daya yang jauh lebih sedikit, dengan keberanian mengambil resiko sehingga mereka harus sangat inovatif dalam mengajukan pemecahan masalah.

8. Orang-orang yang tidak bisa diam, yang ingin memecahkan masalahmasalah yang telah gagal ditangani oleh pranata (negara dan mekanisme pasar) yang ada.

9. Mereka melampaui format-format lama (struktur mapan) dan terdorong untuk menemukan bentuk-bentuk baru organisasi.

10.Mereka lebih bebas dan independen, lebih efektif dan memilih keterlibatan yang lebih produktif.

Ditambahkan lagi oleh Emerson (dalam Nicholls 2006) juga mendefinisikan tipe dari pelaku social entrepreneurship, yakni:

1. Civic innovator (Inovator dari kalangan sipil)

2. Founder of a revenue generating social enterprise (Pendiri social enterprise yang mampu meningkatkan penerimaan)

3. Launcher of a related revenue generating activity to create a surplus to support social vision. (Para aktor yang melaksanakan aktivitas yang berhubungan dengan peningkatan penerimaan yang menciptakan surplus untuk mendukung visi sosial).

\section{Hakikat Kewirausahaan}

Kata wirausaha atau pengusaha diambil dari bahasa Perancis "entrepreneur" yang pada mulanya berarti pemimpin musik atau pertunjukan (Jhingan, 1999). Istilah Wirausaha sering dipakai tumpang tindih dengan istilah Wiraswasta. Ada pandangan yang menyatakan Wiraswasta sebagai pengganti dari entrepreneur sedangkan Wirausaha sebagai pengganti dari entrepreneurship (Suparman Sumahamijya, 1981). Suryana (2003) mendefinifikan kewirausahaan sebagai kemampuan kreatif dan inovatif yang dijadikan dasar, kiat dan sumber daya untuk mencari peluang menuju sukses. Lebih lanjut, Suryana (2003) menjabarkan bahwa kewirausahaan merupakan suatu kemampuan dalam menciptakan nilai tambah di pasar melalui proses pengelolaan sumber daya dengan cara-cara baru dan berbeda melalui Pengembangan teknologi baru, Penemuan pengetahuan ilmiah baru, Perbaikan produk barang dan jasa yang ada, dan Penemuan cara-cara baru untuk menghasilkan barang lebih banyak dengan sumber daya lebih efisien

\section{Jiwa dan Kompetensi Kewirausahaan}

Meredith et al (2002) menjabarkan enam nilai hakiki dalam kewirausahaan yaitu: percaya diri, berorientasi pada tugas dan hasil, keberanian mengambil risiko, kepemimpinan, berorientasi pada masa depan, dan orisinilitas (Kreativitas dan inovasi). Kepercayaan diri merupakan pendorong seseorang untuk berperilaku dan bertindak, orang yang memiliki kepercayaan diri cukup akan cenderung memilki kemampuan untuk bertindak sesuai dengan pemikirannya. Orientintasi pada tugas dan hasil yang dimiliki seseorang akan menimbulkan motif orang untuk berprestasi. Keberanian mengambil risiko merupakan spririt dasar suatu usaha.

Semakin besar keberanian orang mengambil risiko semakin besar pula peluang hasil yang diperoleh. Keberanian mengambil risiko mendorong seseorang untuk berani mengambil tindakan yang baru yang kreatif dan inovatif. Kepemimpinan merupakan ujung tombak dalam pengelolaan usaha. Jiwa kepemimpinan yang baik yang dimiliki seseorang mampu meningkatkan kemampuan menejerial seseorang. Orientasi seseorang pada masa depan mampu mendorong sesorang untuk tetap belajar dan memperbaiki kesalahan sehingga dapat terus maju. Nilai hakiki dari kewirausahaan adalah keorisinilan. Dalam mengembangkan suatu usaha orisinilitas ide dalam menjalankan usaha merupakan motor penggerak utama. Suatu ide yang benarbenar baru mendorong kemajuan usaha itu sendiri.

Lebih lanjut, Jhingan (1999) memberikan kualitas kriteria pengusaha sebagai berikut:

1. Energik, banyak akal, siap siaga terhadap peluang baru, mampu 
menyesuaikan diri terhadap kondisi yang berubah dan mau menanggung resiko dalam perubahan dan perkembangan;

2. Memperkenalkan perubahan teknologi dan memperbaiki kualitas produknya;

3. Mengembangkan skala operasi dan melakukan persekutuan, mengejar dan menginvestasikan kembali labanya

Suryana (2003) menjabarkan bahawa seorang wirausahawan harus memiliki keterampilan dasar yang meliputi

1. Managerial skill untuk pengelolaan usaha,

2. Conceptual skill yaitu kemampuan untuk membuat konsep usaha dan pemetaan pecahan masalah,

3. Human skill yaitu kemampuan untuk berkomunikasi dan beriteraksi dengan orang lain,

4. Decision making skill yaitu kemampuan utuk mengambil keputusan dengan tepat sasaran pada waktu yang tepat juga,

5. Time managerial skill yaitu kemampuan mengelola, mengatur, dan menggunakan waktu.

\section{Menumbuhkan Jiwa Kewirausahan}

Herwan Abdul Muhyi (2007)

menjelaskan cara-cara untuk menumbuhkan jiwa kewirausahaan dapat dilakukan dengan menggunakan empat cara:

1. Melalui pendidikan formal.

Kini berbagai lembaga pendidikan baik menengah maupun tinggi menyajikan berbagai program atau paling tidak mata kuliah kewirausahaan

2. Melalui kewirausahaan. seminar-seminar kewirausahaan seringkali diselenggarakan dengan mengundang pakar dan praktisi kewirausahaan sehingga melalui media ini kita akan membangun jiwa kewirausahaan pada diri kita

3. Melalui pelatihan.

Berbagai simulasi usaha biasanya diberikan melalui pelatihan baik yang dilakukan dalam ruangan (indoor) maupun di luar ruangan (outdoor). Melalui pelatihan ini, keberanian dan ketanggapan kita terhadap dinamika perubahan lingkungan akan diuji dan selalu diperbaiki dan dikembangkan

4. Otodidak.

Melalui berbagai media kita bisa menumbuhkan semangat berwirausaha. Misalnya melalui biografi pengusaha sukses (success story), media televisi, radio majalah koran dan berbagai media yang dapat kita akses untuk menumbuh kembangkan jiwa wirausaha yang ada.

\section{TINJAUAN PUSTAKA}

\section{Khalayak Sasaran Kegiatan PPM}

Khalayak sasaran yang dipilih adalah para keluarga KUP Suta Nusantara (Komunitas Usaha Pertanian Sentra Usaha Tani dan Agribisnis Nusantara) di Surabaya sebanyak 10 anggota keluarga. Penetapan sasaran ini merupakan suatu upaya peningkatan jiwa wirausaha di kalangan keluarga. Lebih jauh dari itu, harapannya peserta pelatihan dapat menularkan ilmu dan jiwa wirausaha yang didapatkan kepada keluarga lainnya dan masyarakat sekitar.

\section{Metode Pelaksanaan}

Pelaksanaan kegiatan Pengabdian Pada Masyarakat ini dilakukan dengan menggunakan metode ceramah dan pratek dalam membuat keripik tempe LUPIN serta modifikasi produk dengan bahan olahan oleh peserta.

\section{Langkah-langkah Kegiatan PPM}

Langkah-langkah kegiatan pengabdian ini adalah sebaga berikut:

- Langkah 1 (Metode Ceramah) :

Peserta diberi motivasi agar memiliki spirit dan jiwa kewirausahaan yang tinggi dan melekat dengan cara mengubah paradigma berfikir peserta terkait dengan kegiatan berwirausaha. Langkah pertama diselenggarakan selama 3 jam.

- Langkah 2 (Metode Diskusi):

Peserta diberikan kasus pemecahan dan konsep pengeloalan usaha dengan tujuan untuk meningkatkan pengetahuan kewirausahaan. Kemudian peserta diberi pelatihan merancang usaha baru dengan membuat business plan yang visible, dan kemudian dipresentasikan di depan 
forum diskusi. Langkah kedua diselenggarakan selama 3 jam.

- Langkah 3 (Pratikum):

Peserta diberikan kasus bagaimana mengelola dan membuat kripik tempe LUPIN. Langkah ketiga diselenggarakan selama 3 jam.

\section{Rencana Pelaksanaan Kegiatan}

Kegiatan pelatihan kewirausahaan bagi keluarga KUP Suta Nusantara (Komunitas Usaha Pertanian Sentra Usaha Tani dan Agribisnis Nusantara) di Surabaya akan dilaksanakan selama dua hari (Tabel $1)$.

Tabel 1. Susunan Pelaksanaan Kegiatan

\begin{tabular}{|c|c|c|c|}
\hline No & $\begin{array}{l}\text { Hari/ } \\
\text { Tanggal }\end{array}$ & Materi & Waktu \\
\hline \multirow[t]{6}{*}{1.} & Selasa, 13 & Pembukaan dan sambutan Ketua & $09.00-09.15$ \\
\hline & Desember & Menumbuhkan spirit kewirausahaan dan memotivasi peserta & $09.15-10.45$ \\
\hline & & Achievement Motivation \& Meningkatkan Kreativitas & $10.45-11.15$ \\
\hline & & Mindset Entrepreneur & $11.15-12.00$ \\
\hline & & ISHOMA & $12.00-13.00$ \\
\hline & & Menyusun business plan & $13.00-14.00$ \\
\hline 2. & $\begin{array}{l}\text { Rabu, } 14 \\
\text { Desember } \\
2016\end{array}$ & Praktikum, membuat kripik tempe LUPIN & $09.00-12.00$ \\
\hline
\end{tabular}

\section{Sumber: Data Primer}

\section{HASIL DAN PEMBAHASAN}

Setelah mengikuti Pelatihan Pengolahan Kripik Tempe Lupin Sebagai Upaya Menumbuhkan Kreatifitas Kewirausahaan Sosial Dan Menggali Ide Usaha Baru, mulai muncul jiwa kewirausahaan sosial dikalangan anggota keluarga KUP Suta Nusantara (Komunitas Usaha Pertanian Sentra Usaha Tani dan Agribisnis Nusantara). Wirausahawan sosial dapat mewujudkan individu yang memiliki solusi inovatif untuk menyelesaikan permasalahan sosial di masyarakat sekitar mereka. Anggota keluarga akan memiliki jiwa yang ambisius dan pantang menyerah dalam menangani masalah sosial yang besar dan menawarkan ide-ide baru untuk membawa perubahan yang lebih luas. Kedelai LUPIN diharapkan dapat menjadi bahan baku yang nantinya tidak hanya keripik tempe tetapi dapat berbagai produk olahan sesuai dengan selera masyarakat.

Ide yang muncul dari kreatifitas yang dimiliki nantinya dapat memotivasi anggota keluarga lainnya untuk terus mencoba dan memperbaharui produk akhir. Dari uraian tersebut ada sesuatu sifat yang ingin diharapkan peneliti sesuai dengan pendapat yang dikemukan Tan et al (2005).

1. Agen perubahan sosial

Mengadopsi misi untuk menciptakan dan mempertahankan nilai sosial (bukan nilai hanya pribadi); Mengenali dan mengejar peluang baru untuk mewujudkan misi tersebut; Melakukan proses inovasi yang berkelanjutan, adaptasi, dan belajar; Bertindak berani tanpa dibatasi oleh sumber daya yang dimiliki; dan Meningkatkan akuntabilitas pada konstituen yang dilayani dan hasil kerja

2. Kreatif dan inovatif

Kreativitas merujuk kepada pembentukan ide-ide baru, sementara inovasi adalah upaya untuk menghasilkan mengatasi masalah dengan menggunakan ide-ide baru tersebut. Dengan demikian, kreativitas merupakan titik permulaan dari setiap inovasi. Inovasi adalah kerja keras yang mengikuti pembentukan ide dan biasanya melibatkan usaha banyak orang dengan keahlian yang bervariasi tetapi saling melengkapi. 
3. Disiplin dan Bekerja keras

Seorang wirausaha melaksanakan kegiatannya dengan penuh perhatian. Rasa tanggung jawabnya tinggi dan tidak mau menyerah, walaupun dia dihadapkan pada rintangan yang mustahil diatasi. Menjalankan organisasi sosial bukan hal yang mudah. Ada banyak hambatan akan dihadapi seperti mengidentifikasi akar masalah sosial, mendapatkan modal, pendanaan, mengelola program, membangkitkanpartisipasi masyarakat, mengkomunikasikan ide/gagasan pada pihak lain dsb. Seluruh masalah itu hanya dapat diatasi dengan mental disiplin dan bekerja keras.

\section{Altruis}

Sikap moral yang memegang prinsip bahwa setiap individu memiliki kewajiban membantu, melayani dan menolong orang lain yang membutuhkan. Tujuan tindakannya adalah kesejahteraan masyarakat secara umum. Wirausaha sosial harus memiliki sifat altruis ini karena seluruh tindakannya didorong oleh keinginan mengatasi masalah sosial. Tentu saja karena bekerja, ia mendapatkan imbalan material namun imbalan ini bukan menjadi pendorong utama.

Dari uraian diatas dapat digambarkan model pelatihan seperti pada gambar 1 .

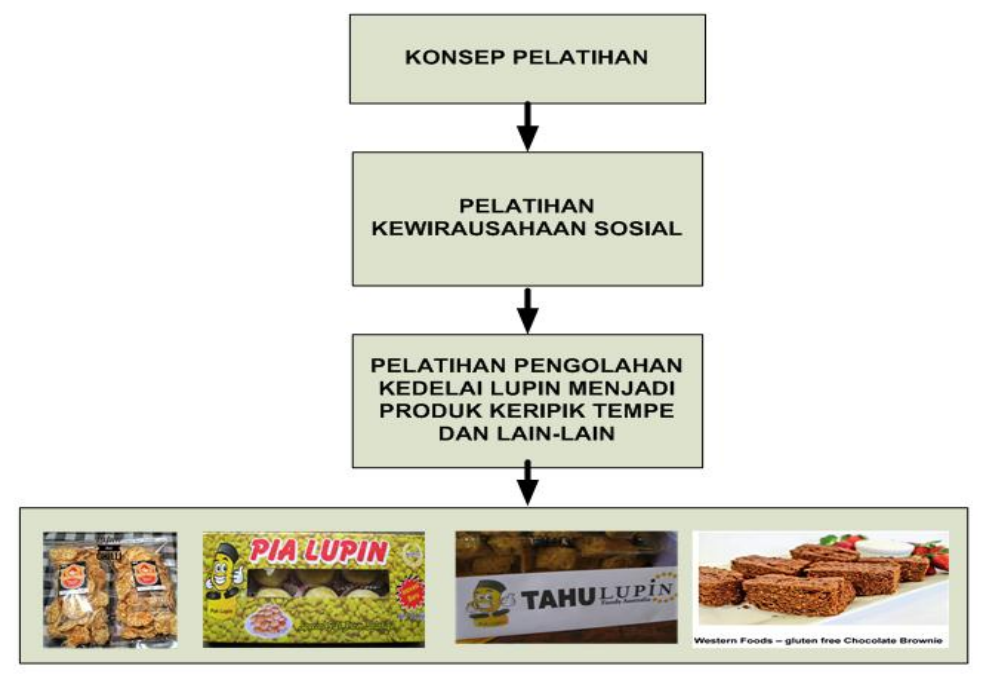

\section{Gambar 1. Model Pelatihan Sumber: Data Primer}

\section{SIMPULAN DAN SARAN \\ Simpulan}

Simpulan dari kegiatan pelatihan kewirausahaan sosial dalam pembuatan kripik tempe LUPIN berlangsung dengan baik. Hal ini ditunjukkan dengan tumbuhnya spirit, motivasi dan kreatifitas dalam menggali ide potensi usaha.

\section{Saran}

Acara pelatihan kewirausahaan sosial bagi anggota keluarga KUP Suta Nusantara perlu ditindaklanjuti melalui pemdampingan. Bagi anggota KUP Suta Nusantara yang sudah memiliki kemampuan dalam mengelola pengembangan kripik tempe LUPIN dapat memberikan pengalamannya kepada anggota lain atau masyarakat sekitar mereka, sehingga misi sosial dapat dijalankan 


\section{DAFTAR PUSTAKA}

Borstein, D. (2006). How to change the world. Socio entrepreneurs and the power of new ideas

Herwan Abdul Muhyi, (2007) Menumbuhkan Jiwa Dan Kompetensi

Hardi Utomo, (2014) Among Makarti, Vol.7 No.14, Desember 2014

Hulgard, Lars (2010). Discourses of Social Entrepreneurship-Variation of The Same Theme? EMES European Research Network.

Geoffrey G. Meredith, et. Al. (2000). Kewirausahaan Teori dan Praktek. Jakarta: Pustaka Binaman Pressindo

Meredith, Geoffrey G. (2002). Kewirausahaan: Teori dan Praktek. Jakarta : PPM

Nicholls, A. (2006). Playing the Field: A New Approach to the Meaning of Social Entrepreneurship. Social Enterprise Journal, 2.1, pp. 1-5;

Suparman Sumahamijaya. (1980). Membina Sikap Mental Wiraswata. Jakarta:Gunung Jati

Suryana. (2003). Kewirausahaan: Pedoman Praktis, Kiat dan Proses Menuju Sukses. Jakarta: Salemba Empat

Kasali Rehald. (2012). Cracking Entrepreneurs. Penerbit PT, Gramedia Pustaka Utama, Jakarta.

Kewirausahaan, Makalah: Jurusan Ilmu Administrasi Niaga Fakultas Ilmu Sosial Dan Ilmu Politik Universitas Padjadjaran Bandung

Tan, Wee-Ling., Williams, John., dan Tan, Teck-Meng. (2005). 'Defining the 'Sosial' in 'Sosial Entrepreneurship': Altruism and Entrepreneurship'. International Entrepreneurship and Management Journal 1, pp 353-365 